\title{
Analysis of Runoff due to The Change in Land Use at The Watershed of Upstream Ciliwung
}

\author{
Dwi Indriastuti \\ Directorate General of Water Resource Management, Ministry of Public Works and Housing, South Jakarta, INDONESIA \\ dweeyisdwi@yahoo.co.uk
}

\begin{abstract}
Climate change triggers extreme climate conditions such as temperature rising, high rainfall intensity, sea water level rising, drought, and others (Thuc, 2014). Challenges in sustainable development are the increasing of various disasters, climate change, and global crisis such as land use change, soil quality degradation, limited water and mineral, environmental pollution, and decrease in biodiversity. The cause of flooding in Jakarta is due to the overflow of Ciliwung River. The change of land use greatly affects the Ciliwung River flow. Land degradation in the upstream of Ciliwung watershed (Puncak area) leads to problems, such as annual flooding, especially in the downstream area. The change of surface that tend to decrease the ability to conserve water, increasing runoff, moreover, the change of land condition which is easily saturated are affected the runoff conditions in Ciliwung watershed. This research used HEC-HMS software in order to know how the land uses changes and rainfall triggering the runoff. By using land use maps in 2000, 2005, 2010, and rainfall data in 5 (five) rainfall station near location from 1996 to 2013, the runoff changes can be known. Parameter calibration was done with the measured discharge in Katulampa Weir for each event. Simulation by HEC HMS used CN value of Spatial Planning in Ciliwung upstream area and 25 years rainfall return period showed that the highest discharge was $226.25 \mathrm{~m}^{3} / \mathrm{second}$, and water level reaches $317 \mathrm{~cm}$. If the alert in Katulampa Weir was considered, then the condition turned to Alert 1 during \pm 6 hours.
\end{abstract}

Keywords: Ciliwung, runoff, land utilization, rainfall.

\section{INTRODUCTION}

Climate change leads to extreme climate condition such as the rise in temperature, the high rainfall, the rising sea levels, drought and so on (Thuc, 2014). Several challenges of sustainable development are the increase of the disasters, the climate change and, a global crisis such as the changes in land use, soil quality degradation, the limitations of water and mineral, the increasing of environmental pollution and the decreasing of the amount of biodiversity. Floods and droughts in the watershed are caused by a climate phenomenon, which is the distribution of a high-intensity rainfall or a longer drought period. Flooding is derived from the input (rainfall) and watershed system. Input (rainfall) is included the rainfall intensity factor, duration, and distribution. While the watershed system is included topography factors, soil types, land use and rainfall transfer system in the watershed (Agus \& Hadihardaja, 2011).

The need for conservation in the upstream area and control of water damage can be a solution to excessive runoff discharge. Some areas covered with vegetation changed into a commercial area in the watershed of upstream Ciliwung during 1981 until 1999. There was a conversion of forest land, mixed garden, technical irrigated field, rain fed field and moor into the residential area of 250 hectares (Irianto,
2000). Sabar (2007) stated that the land conversion on watershed of upstream Ciliwung during the period 1990 to 1999 was relatively rapid, it marked by an increase in urban solid area by $20.3 \%$. One of the goals of this research was to discover the runoff that caused by changes in land use, especially runoff that occurs with the use of land in accordance with the Bogor Regency spatial planning, and how will it affect the alert levels at Katulampa Weir.

\section{LITERATURE REVIEW}

Changes in watersheds land use provide quite a dominant influence on flood discharge (Jayadi, 2002). Watershed ecosystems, particularly the upstream part is important because it has the function to protect against the overall part of watershed. This protection is, among others, setting the function of the water system and the land use. Seyhan (1977) in Gunawan and Hartono (2000) stated that watershed characteristics can be grouped into two categories. They are land factors (topography, soils, geology, and geomorphology) and the factors of vegetation and land use. The land is a limited natural resource. The increasing needs for human of land resource give specific patterns on land use in a region. The impacts are the occurrence of changes in land use, such as change of land use from forest to agriculture and other land use, which can interfere the stability of the 
water and the land (Asdak, 2010). Chapin (1995) in Ratna (2003) stated that factors which influence the development of land use, among others are the topography, the higher the topography is, the lower the level of land use will be; the population, the more people are, the more change of land use would occur; the value of land, the more expensive the land because of its strategic location is, the sooner changes would occur; the accessibility, the higher the level of accessibility is, the larger the change of land use would be; the availability of existing infrastructure and facilities would accelerate the change of land use and; the environmental carrying capacity.

Asdak (2010) defined watershed as an area of land that is topographically bordered by mountain ridges which store rain water. Suripin (2002) mentioned that as an area, watershed is restricted by nature, such as the ridge of hills or mountains, or artificial boundaries, such as a road or embankment, in which the rainfall occurs contributes to flows to the control point. Downstream part of watershed is an area of land in the watershed that is characterized by flat to sloping topography with mild slope $(<8 \%)$, low density and a drainage area or alluvial sediments and in some places are flooded areas (inundation). While the center part of the watershed was an area of transition between the two bio-geophysics characteristics of upstream and downstream part of watershed. Ecosystems that formed on the upstream of the watershed hold a vital role because it has the function to protect against all parts of the watershed. Therefore, the upstream part of the watershed often becomes the focus of watershed management planning.

Modeling is a simplifying way to describe complicated process that occurs in nature into figure or mathematical language, based on the norms that apply, in order to be easily understood. Thus, hydrology model is a simple presentation of a complex system on hydrology. Hydrological model for flood management consisted of two related parts, i.e. model for planning and operation model. Flood discharge prediction method consists of a rational method, empirical methods, hydrograph unit methods, and method of flood frequency (Indriastuti, 2015). In general, hydrology model is an imitation of hydrology process, for analysis purpose on the water existence according to the aspect of quantity, time, place, probability and time series, or a simple review of a complex hydrologic system (Sri Harto, 2000).

\section{RESEARCH METHODS}

The data used in this research were as follows:

a) Land use map for different years. In this study, the researcher used maps of land use in 2000, 2005, 2010 and Spatial Plan area (Spatial Planning) obtained from Development Planning Agency at Sub-National Level Office of Bogor Regency,

b) Daily and monthly rainfall data in watershed of upstream Ciliwung River. This research used 5 rainfall stations located at Ciliwung upstream watershed: rainfall stations of Ciawi, Gadog, Citeko, Gunung Mas and Cilember,

c) Measured discharge data and its rating curve that was taken from Office of Ciliwung Cisadane River Area and Office of Hydrology Central Research and Development of Water Resources

To determine the boundaries of watershed and sub watershed, the highest dots or peaks where the expected rainfall will be collected and streamed on the watershed were being connected. To determine the boundaries of the watershed and sub watershed, a Topographical map of Indonesia which released in 2010 was being used. Sites that were being reviewed in this study were from the Katulampa AWLR station up to the watershed of upstream Ciliwung which is in the area of Mount Gede Pangrango, West Java.

Land use information used in this study was obtained from a map of land use that was made by Development Planning Agency at Sub-National Level Office of Bogor district in the years 2000, 2005 and 2010. Based on the three maps, land use changes in the watershed of upstream Ciliwung could be known.

To determine the value of the $\mathrm{CN}_{\text {composite }}$ for each subwatershed, this research used the $\mathrm{CN}$ reference value based on the land use on average conditions (Antecedent Moisture Condition II/AMC II) that was used by Office of Cisadane Ciliwung River Watershed Management (BPDAS) as shown in Table 1. 


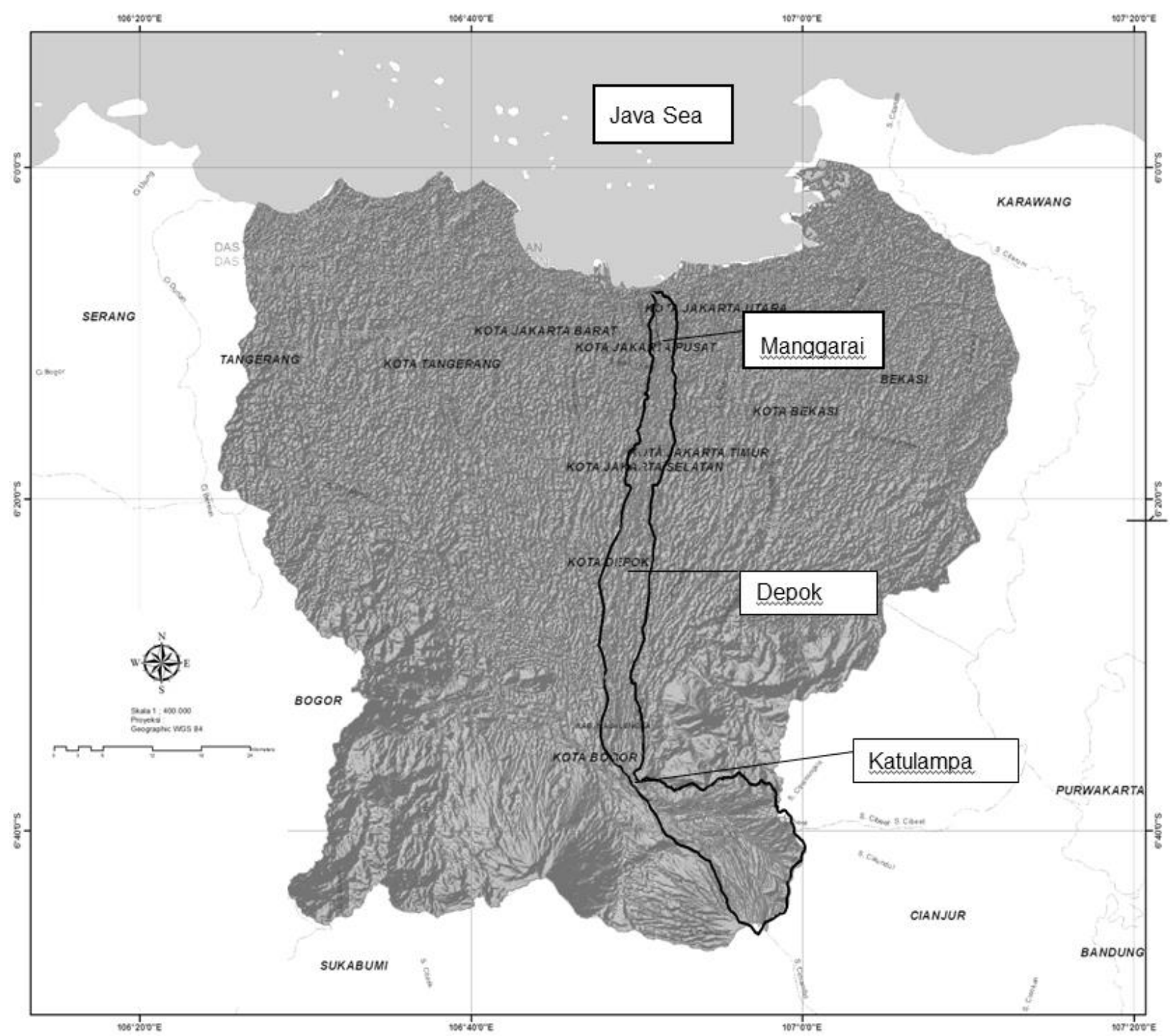

Figure 1. Ciliwung Watershed in Jabodetabek map (research location).

\section{RESEARCH RESULTS AND DISCUSSION}

\subsection{Research Location}

The research was located in watershed of upstream Ciliwung, with Katulampa AWLR in Bogor, West Java as the observation point as shown in Figure 1. The area of research was approximately $148.85 \mathrm{~km}^{2}$.

Table 1.Value soil classification based on land use

\begin{tabular}{lllll}
\hline Land use & A & B & C & D \\
\hline Forest & 25 & 55 & 70 & 77 \\
Bush/Shrub & 36 & 60 & 73 & 79 \\
Grass/vacant lot & 39 & 61 & 74 & 80 \\
Moor/lading & 49 & 69 & 79 & 84 \\
Plantation & 45 & 66 & 77 & 83 \\
The settlements & 74 & 83 & 89 & 91 \\
Buildings & 98 & 98 & 98 & 98 \\
Rice fields & 61 & 73 & 81 & 84 \\
Fresh water & 100 & 100 & 100 & 100 \\
Swamp & 75 & 80 & 85 & 90 \\
\hline
\end{tabular}

\subsection{Identification of Watershed Parameters}

Based on the analysis results which used the topographical map as shown in Figure 2, watershed of upstream Ciliwung is divided into 4 sub watersheds, namely Ciesek, Cisarua, Ciawi and Cisukabirus with land coverage of each sub watershed on Table 2.

Table 2. Area of each sub-watershed

\begin{tabular}{lll}
\hline No & Name of sub-watershed & Area $\left(\mathrm{km}^{2}\right)$ \\
\hline 1 & Ciawi & 19.54 \\
2 & Ciesek & 20.54 \\
3 & Cisarua & 80.87 \\
4 & Cisukabirus & 27.82 \\
\hline
\end{tabular}

Each sub-watershed has a land use that varies by year. Table 3 and Figure 3 describe land use in each sub-watershed of upstream Ciliwung in 2000, 2005, 2010 and the spatial planning. 


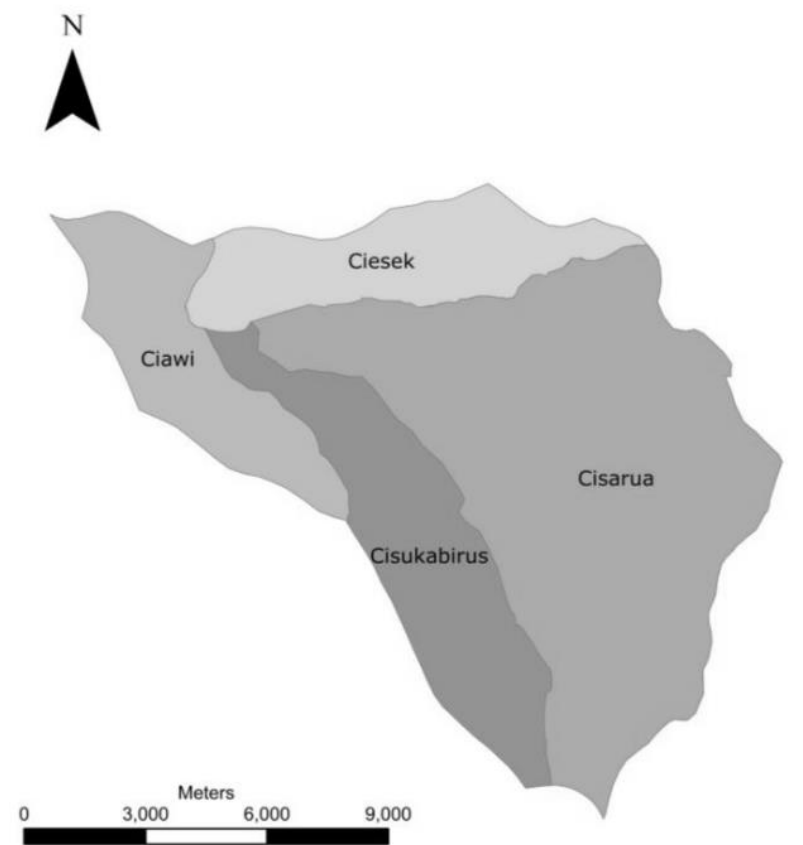

Figure 2.Sub-watersheds division

Table 3. Composition of land use change

\begin{tabular}{lllll}
\hline Land use & $\begin{array}{c}2000 \\
(\%)\end{array}$ & $\begin{array}{l}2005 \\
(\%)\end{array}$ & $\begin{array}{l}2010 \\
(\%)\end{array}$ & $\begin{array}{l}\text { Land use } \\
\text { percentage of } \\
\text { spatial } \\
\text { planning }(\%)\end{array}$ \\
\hline Water existing & 0.37 & 0.31 & 0.31 & 0.31 \\
Forest & 49.15 & 28.30 & 29.14 & 49.06 \\
Garden & 20.05 & 37.36 & 23.41 & 8.07 \\
Houses & 22.07 & 23.04 & 40.71 & 23.71 \\
Farmland & 2.54 & 5.57 & 2.64 & 18.84 \\
Bushes & 5.83 & 5.43 & 3.80 & 0.00 \\
Total & 100 & 100 & 100 & 100 \\
\hline
\end{tabular}

Table 4. CN value changes for each sub-watershed

\begin{tabular}{llll}
\hline \multirow{2}{*}{ Sub-watershed } & \multicolumn{3}{c}{ Year } \\
\cline { 2 - 4 } & 2000 & 2005 & 2010 \\
\hline Ciawi & 68.20 & 74.89 & 79.46 \\
Ciesek & 65.38 & 67.57 & 69.01 \\
Cisukabirus & 41.54 & 47.24 & 54.24 \\
Cisarua & 41.59 & 45.00 & 51.14 \\
\hline
\end{tabular}

\subsection{Spatial Planning}

The research calculated water levels that occur if the land use in the watershed of upstream Ciliwung is in accordance with the Bogor Regency spatial planning of 2005-2025 with the input rainfall return period of 25 years.

With the composition of the land use such in Table 3 and $\mathrm{CN}$ value for each land use as in Table 1 above, it can be known the $\mathrm{CN}$ values for each sub watershed. Table 5 describes the $\mathrm{CN}$ values for each sub-watershed.
Table 5. CN value for each sub-watershed according to Spatial Planning

\begin{tabular}{ll}
\hline Sub-watershed & Curve Number \\
& RTRW 2005-2025 \\
\hline Ciawi & 80.74 \\
Ciesek & 64.55 \\
Cisukabirus & 42.87 \\
Cisarua & 40.59 \\
\hline
\end{tabular}

\subsection{Analysis of Watershed Rainfall}

Maximum rainfall per year on each rainfall station was multiplied by the weight generated the watershed annual maximum rainfall, with the results in Table 6. The distribution of duration rainfall used in this research was in accordance with the characteristics of one of the rainfall station watershed of upstream Ciliwung. In his research Priambodo (2004) concluded some of the characteristics of the rainfall station in watershed of Ciliwung River from its upstream to its downstream. For watershed of upstream Ciliwung, the rainfall station used was Citeko rainfall station. From the research, the distribution of the rainfall for Citeko rainfall station for 5 hours was $38 \%, 28 \%, 11 \%, 14 \%$ and $9 \%$.

Table 6.Watershed rainfall calculation

\begin{tabular}{lll}
\hline No & Year & Watershed Rainfall (mm/day) \\
\hline 1 & 1996 & 86.08 \\
2 & 1997 & 62.07 \\
3 & 1998 & 75.18 \\
4 & 1999 & 64.85 \\
5 & 2000 & 81.04 \\
6 & 2001 & 94.94 \\
7 & 2002 & 138.55 \\
8 & 2003 & 89.94 \\
9 & 2004 & 95.24 \\
10 & 2005 & 114.83 \\
11 & 2006 & 109.08 \\
12 & 2007 & 160.62 \\
13 & 2008 & 76.23 \\
14 & 2009 & 125.06 \\
15 & 2010 & 77.35 \\
16 & 2011 & 95.69 \\
17 & 2012 & 67.03 \\
18 & 2013 & 59.55 \\
\hline
\end{tabular}

\subsection{Calibration}

The calibration aimed to obtain quantity parameters that are hard to get if real measurements are conducted. This process required some field data in the same time period. So the quantity parameters were expected to come close to the real situation. At this stage, all parameters were calibrated except $\mathrm{CN}$. The calibration continues until the peak discharge values reached their closest value. 
To determine which calibration was considered to be representative of the Area Upstream watershed model, the suitability of hydrograph form, the percentage of error between simulations and observations, the values of the Root Mean Square Error (RMSE) and Nash Sufficient Efficiency (NSE) needed to be checked. RMSE required the value of close to 1 (one) (Moriasi, 2007). From the three calibrations aforementioned, it could result in the

\section{$\hat{\Lambda}$}

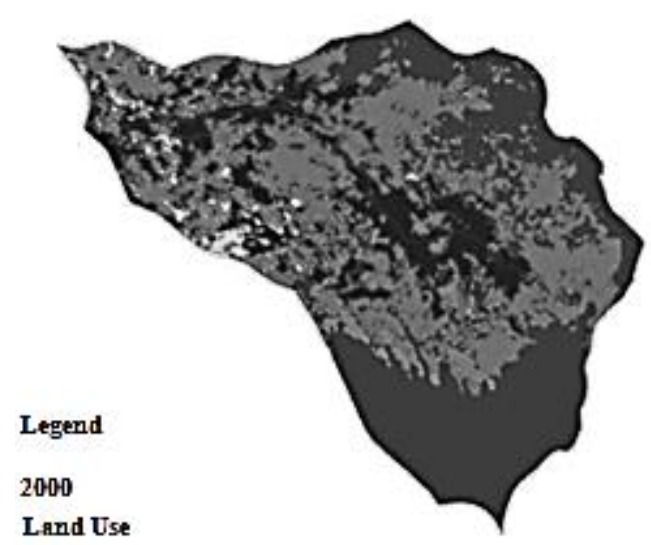

Land Use

Forest

Farm

Houses

Rice Field

Bush

Water Body

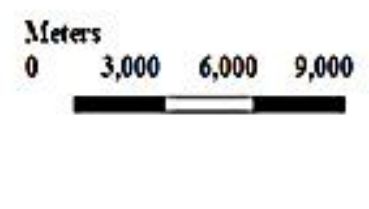

A

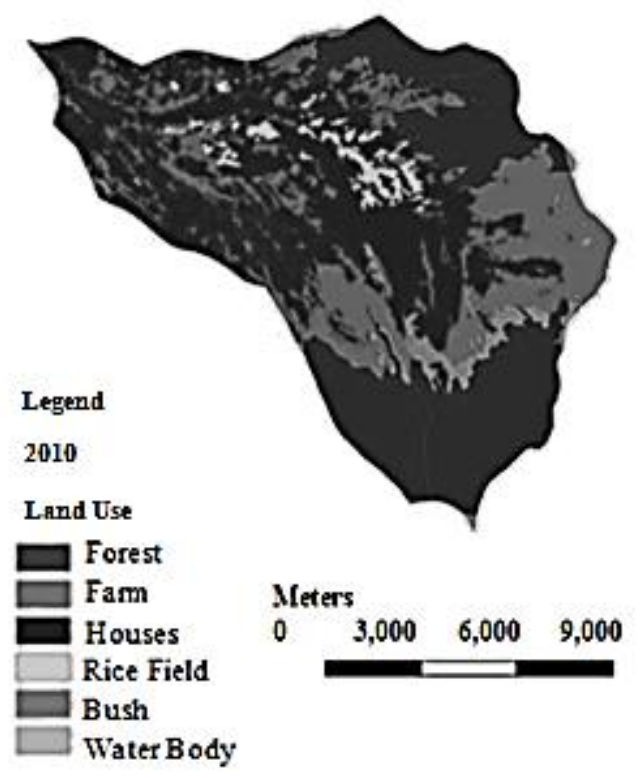

error simulation percentage, RMSE, and NSE values as shown in Table 7.

From the three calibration corresponding to the value of the suitability of the correlation in the table above, it was concluded that the appropriate calibration was the calibration that happened in 2005 with RMSE and NSE values most close to 1 (one), in consecutive of which $5.67 \mathrm{~m}^{3} / \mathrm{s}$ and 0.836 .
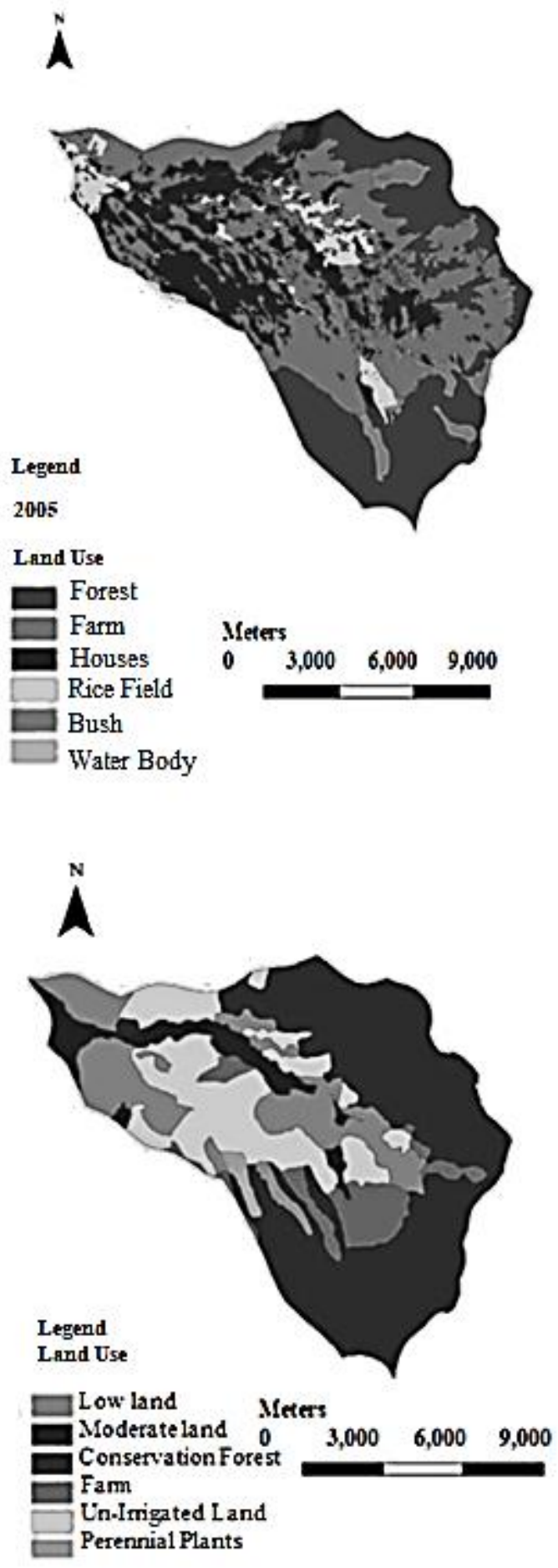

Figure 3. Land use map of Watershed of Ciliwung Upstream in 2000, 2005, 2010 and Spatial Planning 
Table 7. Comparison of simulation results and observations

\begin{tabular}{|c|c|c|c|c|c|c|}
\hline Date & Parameter & $\begin{array}{l}\text { Simulation } \\
\text { results }\end{array}$ & Observation & $\%$ Error & $\begin{array}{l}\text { RMSE of } \\
\text { peak flow }\end{array}$ & NSE \\
\hline \multirow{2}{*}{ 2-3 February 2000} & Water depth & $10.92 \mathrm{~mm}$ & $8.22 \mathrm{~mm}$ & 32.85 & \multirow[t]{2}{*}{6.70} & \multirow[t]{2}{*}{0.785} \\
\hline & Peak discharge & $69.73 \mathrm{~m}^{3} / \mathrm{s}$ & $57.32 \mathrm{~m}^{3} / \mathrm{s}$ & 21.65 & & \\
\hline \multirow{2}{*}{ 22-23 January 2005} & Water depth & $14.34 \mathrm{~mm}$ & $14.86 \mathrm{~mm}$ & 3.50 & \multirow[t]{2}{*}{5.67} & \multirow[t]{2}{*}{0.836} \\
\hline & Peak discharge & $73.57 \mathrm{~m}^{3} / \mathrm{s}$ & $72.55 \mathrm{~m}^{3} / \mathrm{s}$ & 1.41 & & \\
\hline \multirow{2}{*}{ 16-17 February 2010} & Water depth & $5.48 \mathrm{~mm}$ & $6.77 \mathrm{~mm}$ & 19.05 & \multirow[t]{2}{*}{5.88} & \multirow[t]{2}{*}{0.554} \\
\hline & Peak discharge & $29.14 \mathrm{~m}^{3} / \mathrm{s}$ & $30.10 \mathrm{~m}^{3} / \mathrm{s}$ & 3.19 & & \\
\hline
\end{tabular}

\subsection{Verification}

The verification process aimed to retest the suitability of the model. In this process the optimization result of the parameters became the parameters input of the watershed, replacing the parameters input before stimulation. This verification used hourly discharge data that measured in AWLR times-Katulampa which was on January $22^{\text {nd }}$ at 07:00 until January $23^{\text {rd }}$ at 06:00 in 2005, and is verified at the event on February $16^{\text {th }}$ at $07: 00$ until February $17^{\text {th }}$ at $16: 00$ 2010 as shown in Figure 4. With the results of the verification, it may be determined whether such parameters can be used for other events. The suitability of the sub-watershed parameters on each reviewed year was observed by looking at the calculated hydrograph and the measured hydrograph that were similar or close to similar.

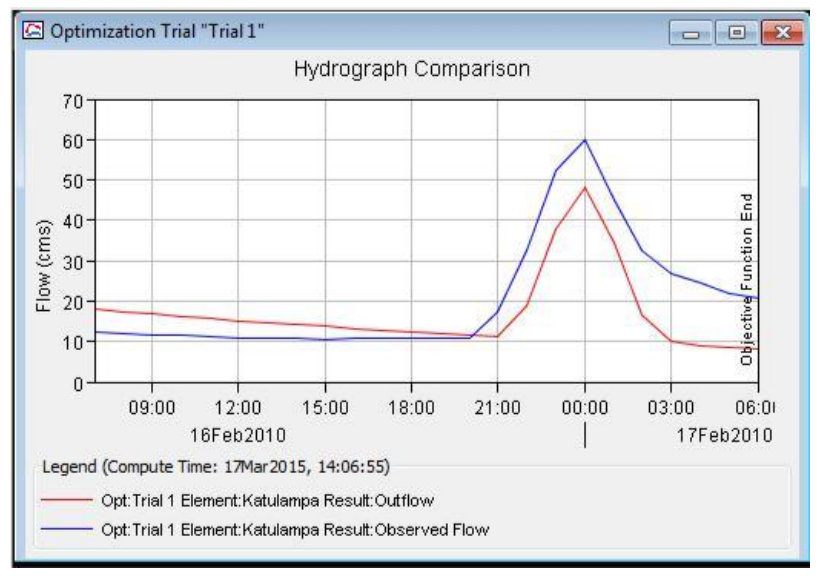

Figure 4. Parameter verification in 2010.

\subsection{HEC-HMS Calculation}

Inputs that were used in the calculation of the HEC HMS are as follows:

a) The obtained parameters from the calibration results. By paying attention to the hydrograph display, the hydrograph error at each calibration results, and the RMSE values as well as NSE gave in table 4.2 above, then the parameters that can be used as the parameters of the calibration results in 2005.

b) Rainfall with return period of 25 years was in accordance with the characteristics of rainfall station in Citeko at watershed of upstream Ciliwung.

c) The Spatial Planning $\mathrm{CN}$ values of each sub watershed.

After these three inputs were calculated by the HECHMS Software, the result was the hydrograph. In this research, hydrograph was the curve that showed the connection between flow and water level height toward time. From the above calculation, the highest discharge generated was of $226.25 \mathrm{~m}^{3} / \mathrm{s}$ with water level height reached 3.17 meters. Compared to the change of land use in the year 2010, there was an increase in discharge and water level height shown in Figure 4.

\subsection{Katulampa Weir}

The Katulampa Weir has alert status criteria created by Department of Public Works of Jakarta report that based on observation stations or the posts and the floodgates (Pintu Air-PA), i.e. alert I, alert II, alert III, and alert IV. Alert I is if the water reaches to > $200 \mathrm{~cm}$, alert II is when water reaches to $150-200 \mathrm{~cm}$, alert III is when it reaches $80-150 \mathrm{~cm}$ and alert IV is when water reaches to $80 \mathrm{~cm}$. (media center. 2014). From the simulations results above, the maximum water level height was 3.17 meters or equivalent to $317 \mathrm{~cm}$. In accordance with the results in Figure 5, the height reached to $>200 \mathrm{~cm}$ (Alert I) for \pm 6 hours with peak discharge was $226.25 \mathrm{~m}^{3} / \mathrm{s}$ in the 7 th hour. Then, the comparison was attempted with the condition of land use change in 2010, in which there was case of increasing $\mathrm{CN}$ in Ciesek, Cisukabirus and Cisarua sub watersheds. Simulations of HEC-HMS with $\mathrm{CN}$ in 2010 delivered larger runoff discharge which was $311.46 \mathrm{~m}^{3} / \mathrm{s}$ with water level height of $3.70 \mathrm{~m}$ and a longer Alert I condition which was approximately 8 hours (Figure 6). 


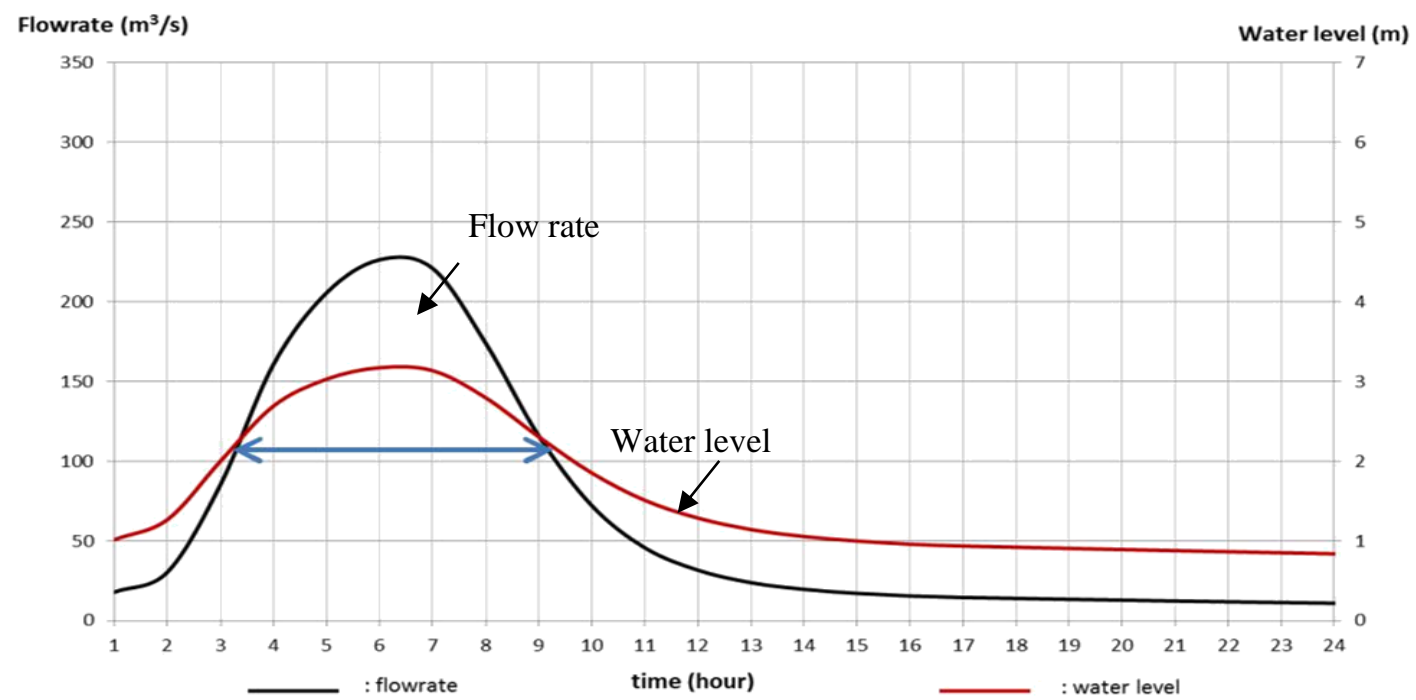

Figure 5. Hydrograph of HEC-HMS simulation results

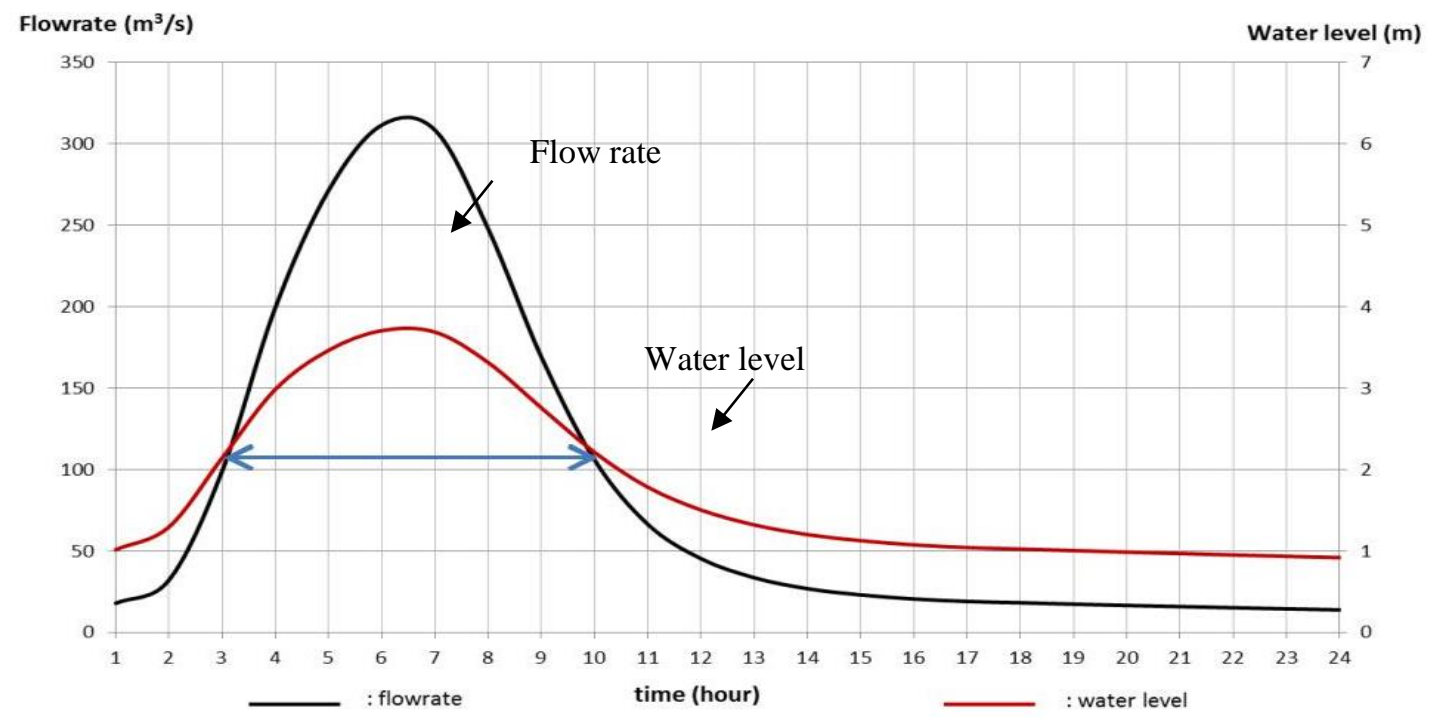

Figure 6. Hydrograph with land use in 2010

Discharge increase was caused by changes in the $\mathrm{CN}$ value, which was the land use change in 2010. From both of the runoff discharge, it showed that changes in land use would affect runoff. This discharge influenced the water level height and Alert levels on the Katulampa Weir. The Alert level I, which is water level height $>200 \mathrm{~cm}$, with land use condition in 2010 , would result in a longer time of approximately 2 hours compared with levels of Alert I with land use matches the Spatial Region as planned in 2005-2025

\section{CONCLUSIONS AND SUGGESTIONS}

\subsection{Conclusions}

From the conducted research, several things that can be made as the conclusions are: a) The area of land use for settlement increased by $18.64 \%$ in the past 10 years, which resulted in an increase in the average $\mathrm{CN}$ rating on subwatershed of upstream Ciliwung from 54.17 become 63.46. The increase in $\mathrm{CN}$ occurred in every sub-watershed were very visible especially in the Ciawi and Ciesek sub watershed. This was due to an increased number of settlements in both of the sub-watersheds, as well as due to differences in soil types with another subwatershed, Cisukabirus and sub-Cisarua. The forest that is considered a protected conservation area also mostly located in the Cisarua and Cisukabirus sub-watershed.

b) Calculations with the help of HEC HMS Software in this research delivered the result of the 
maximum discharge that may occur with the use period of 25-year of rainfall reaches $226.25 \mathrm{~m}^{3} / \mathrm{s}$ at a water level height of $317 \mathrm{~cm}$. This height is classified in Alert level I. Compared with land use in 2010, where there was rise in $\mathrm{CN}$ on Ciesek, Cisukabirus and Cisarua sub watersheds, the resulting larger discharge which was $311.46 \mathrm{~m}^{3} / \mathrm{s}$ at water level height of $370 \mathrm{~cm}$.

c) The Alert I condition, which is when the water height in Katulampa Weir $>200 \mathrm{~cm}$ on the state of land use in the year 2010 gave longer time which was \pm 2 hours, compared to the alert rate on the appropriate land use spatial planning.

\subsection{Suggestions}

Watershed of upstream Ciliwung River which passes through the city of Jakarta is considered to have a large influence in the flooding on Jakarta every year. This research attempted to simulate the land use in accordance with spatial planning with return period rainfall of 25-year by using parameters obtained from the calibration results that happened in 2000, 2005 and 2010. The most noticed input parameter was the land use change, due to its influence on the watershed characteristic. Availability of rainfall data on research site has effect to the rainfall return period that will be exceeded. The accuracy of choosing the flood events as the model has effect in order to get the parameter values that correspond to the characteristics of the watershed. One of the difficulties experienced during this research was at the stage of calibration. The search of pairing of the rainfall time and the resulted discharge must be exactly or close to, in order to facilitate the reading of the comparison charts between observations and simulations. of appropriate land spatial planning and the return

\section{REFERENCES}

Agus, I. \& Hadihardaja, I. K., 2011. Perbandingan Hidrograf Satuan Teoritis terhadap Hidrograf Satuan Observasi DAS Ciliwung Hulu [Comparison of Theoritical Unit Hydrograph and Observed Unit Hydrograph in Upstream Ciliwung Watershed]. Jurnal Teknik Sipil.

Asdak, C., 2010. Hidrologi dan Pengelolaan Daerah Aliran Sungai [Hydrology and Watershed Mangement]. Yogyakarta: Gadjah Mada University Press.

Indriastuti, D., 2015. Analisa Limpasan Akibat Perubahan Tata Guna Lahan pada DAS Ciliwung Hulu [Runoff Analysis Affected by Land Use Change in Upstream Ciliwung Watershed], Yogyakarta: Universitas Gadjah Mada.

Jayadi, R., 2002. Bahan Kuliah MPBA [Lecture Note], Yogyakarta.

Moriasi, e. a., 2007. Model Evaluation Guidelines for Systematic Quantification of Accuracy in Watershed Simulations. America: ASABE.

Priambodo, 2004. Karakteristik Hujan di Beberapa Stasiun Hujan di Wilayah DKI Jakarta [Rainfall Characteristics in Several Rainfall Stations in Jakarta Province], Yogyakarta.

Sri Harto, B., 2000. Analisis Hidrologi [Hydrology Analysis]. Jakarta: PT.Gramedia Pustaka Utama.

Thuc, T., 2014. Impacts on Climate Change. Tokyo, UNU-IAS. 